\title{
Synthesis of heterocyclic natural products: Model studies towards diazonamide $A$
}

\author{
Christopher J. Moody, ${ }^{a}$ Kevin J. Doyle, ${ }^{a}$ Mark C. Elliott, ${ }^{a}$ \\ and Timothy J. Mowlem ${ }^{b}$

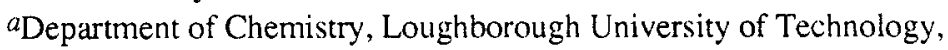 \\ Loughborough, Leicestershire LE11 3TU, U.K.; ${ }^{b}$ Shell Research Ltd, Sittingbourne \\ Research Centre, Sittingbourne, Kent ME9 8AG, U.K.
}

\begin{abstract}
Model studies towards the total synthesis of the cytotoxic marine natural product diazonamide $\mathrm{A}$ are described. The approach uses rhodium(II) catalysed reactions of diazocarbonyl compounds in 4 key steps; the construction of the oxazole rings by the rhodium(II) catalysed addition of diazocarbonyl compounds to nitriles, and of the indole and benzofuran units by rhodium(II) mediated intramolecular aromatic $\mathrm{C}-\mathrm{H}$ insertion reactions.
\end{abstract}

Recently the isolation of a number of oxazole containing natural products, particularly from marine sources, has caused a renewed interest in the chemistry of oxazoles. Naturally occurring oxazoles range in structure from relatively simple 2,5-substituted derivatives such as pimprinine (q.v.) to more complex bis-oxazoles such as the diazonamides. The diazonamides, exemplified by diazonamide $\mathrm{A}$, isolated from the ascidan Diazona chinensis,(1) show potent anticancer activity, and their unique bis-oxazolylindole structure coupled to a dihydrobenzofuran makes them attractive targets for synthesis. We now report the results of model studies towards diazonamide $\mathrm{A}$, using rhodium(II) catalysed reactions of diazocarbonyl conpounds in 4 key steps, viz. the construction of the oxazole rings by the rhodium(II) catalysed addition of diazocarbonyl compounds to nitriles, and of the indole and benzofuran units by rhodium(II) mediated intramolecular aromatic $\mathrm{C}-\mathrm{H}$ insertion reactions.

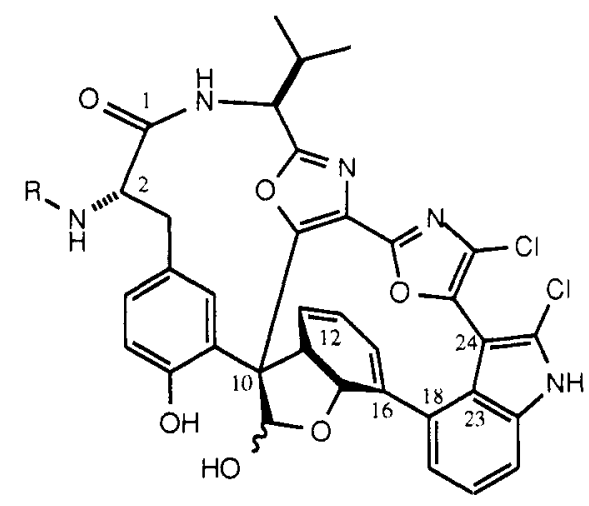

Diazonamide $A\left(\mathrm{R}=\mathrm{COCH}\left(\mathrm{NH}_{2}\right) \mathrm{CHMe}_{2}\right.$

\section{4 steps involve diazocarbonyl chemistry}

2 oxaroles by addition to nitriles

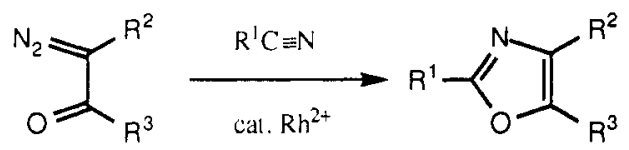

C-10 - C-12 by intramolecular carbenoid C-H insertion

C-23 - C-24 by intramolecular carbenoid C-H insertion

\section{Synthesis of 3-(Oxazol-5-yl)indoles}

The formation of oxazoles by reaction of diazocarbonyl compounds with nitriles can be effected under thermal, photochemical, Lewis acid or transition-metal catalysis, although the latter conditions are often the 
higher yielding and most synthetically useful.(2) In previous studies we have shown that the rhodium(II) catalysed addition of simple diazocarbonyl compounds to nitriles can be extended to include sulfonyl, phosphonyl and nitrile containing diazo compounds, and in the last case, the resulting 4-cyanooxazole can be elaborated into a bis-oxazole in 2 further steps (Scheme 1).(3)

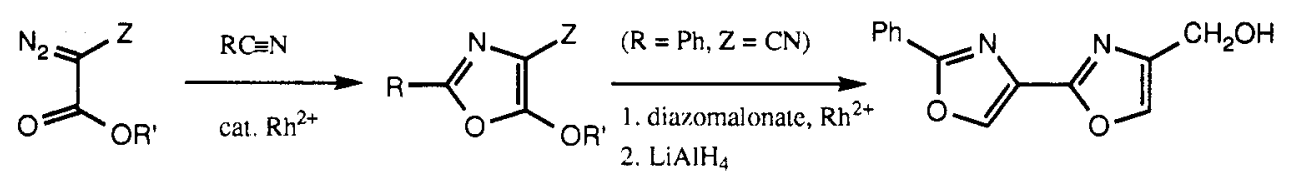

\section{Scheme 1}

In order to apply this methodology to the oxazolylindole fragments of diazonamide $\mathrm{A}$, we required a route to diazoacetyl indoles. The $N$-protected diazoacetylindole 1 was readily prepared from 3-acetylindole using the modified diazo transfer procedure developed by Danheiser.(4) Rhodium(II) acetate catalysed decomposition of 1 in boiling acetonitrile gave the desired 3-(oxazol-5-yl)indole $2(\mathrm{R}=\mathrm{Me})$ in $40 \%$ yield, deprotection of which with sodium methoxide in methanol/THF gave the oxazolylindole $3(\mathrm{R}=\mathrm{Me})$ $(74 \%)$. Interestingly, the oxazolylindole $3(\mathrm{R}=\mathrm{Me})$ is a natural product, pimprinine.(5) The closely related oxazolylindole alkaloid pimprinethine $3(R=E t)$ was also prepared from 1 by a similar route, although in this case the use of rhodium(II) trifluoroacetamide, a more active catalyst for certain carbenoid transformations, (6) was necessary. Thus reaction of 1 with propionitrile at room temperature in the presence of rhodium(II) trifluoroacetamide gave the oxazolylindole $2(R=E t)$ in $90 \%$ yield, deprotection of which as above gave pimprinethine $(78 \%)$ (Scheme 2$)$.<smiles>CC(=O)c1c[nH]c2ccccc12</smiles><smiles>Pc1ncc(-c2c[nH]c3ccccc23)o1</smiles>

3
LiHMDS, THF, $-78^{\circ} \mathrm{C}$ $\mathrm{CF}_{3} \mathrm{CO}_{2} \mathrm{CH}_{2} \mathrm{CF}_{3}, \mathrm{MsN}_{3}, \mathrm{Et}_{3} \mathrm{~N}$<smiles>N#CC(=O)c1c[nH]c2ccccc12</smiles>

1<smiles>[R17]N=[R10]=[W]</smiles>

$$
\begin{array}{ll}
\mathrm{R}=\mathrm{Me} & \text { pimprinine } \\
\mathrm{R}=\mathrm{Et} & \text { pimprinethine }
\end{array}
$$

NaOMe, THF

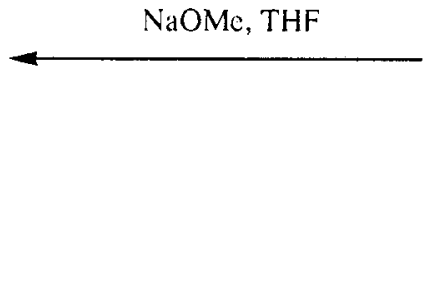

\section{Scheme 2}

\section{Synthesis of Oxindoles}

Since 3-acetyl-2-chloroindoles, required for the synthesis of a correctly substituted oxazolylindole, are readily prepared from oxindoles by reaction with dimethylacetamide $/ \mathrm{POCl}_{3}$, we therefore turned our attention to the synthesis of a suitably substituted oxindole as a precursor to the desired 2,3,4-trisubstituted 
use another carbenoid reaction, viz. the rhodium(II) catalysed decomposition of diazoanilides. The preparation and rhodium(II) catalysed decomposition of diazoanilides has been investigated previously; (810) intramolecular aromatic $\mathrm{C}-\mathrm{H}$ insertion leads to oxindoles, although reaction at the non-aromatic $\mathrm{N}$ substituent has also been observed. Although $N$-aryldiazomalonamic derivatives are reported not to give oxindoles on treatment with rhodium(II) acetate, the ester group apparently preventing aromatic $\mathrm{C}-\mathrm{H}$ insertion by the carbenoid, we decided to reinvestigate these reactions using alternative rhodium catalysts.

The starting diazoanilides 4 were prepared from the corresponding anilines by acylation with ethyl 2 diazomalonyl chloride,(11) readily obtained by the reaction of ethyl diazoacetate with triphosgene.(12) Rhodium(II) acetate catalysed decomposition of the $N$-methyl diazoanilide 4 a resulted in formation of the alcohol 5 , by insertion of the carbenoid into adventitious water, thereby confirming the results reported by Durst and co-workers.(9) Likewise, rhodium(II) acetate catalysed decomposition of the $N$-benzyl diazoanilide $4 \mathrm{~b}$ gave the $\beta$-lactam 6 , in a reaction analogous to that described by Wee and co-workers.(10a) However when both diazoanilides were treated with a catalytic amount of rhodium(II) trifluoroacetamide, the oxindoles 7 were formed in good yield (Scheme 3). Thus the rhodium(II) mediated decomposition of diazoanilides $\mathbf{4}$ is subject to a remarkable catalyst effect, the perfluorinated carboxamide ligand strongly favouring aromatic $\mathrm{C}-\mathrm{H}$ insertion. The slightly tedious preparation of rhodium(II) trifluoroacetamide can be avoided by its 'in situ' generation from rhodium(II) acetate and trifluoroacetamide.

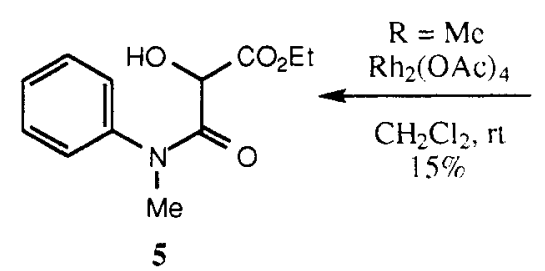<smiles>CCOC(=O)C(=N)C(=O)N(P)c1ccccc1</smiles>

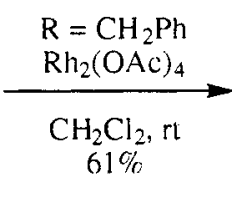

4

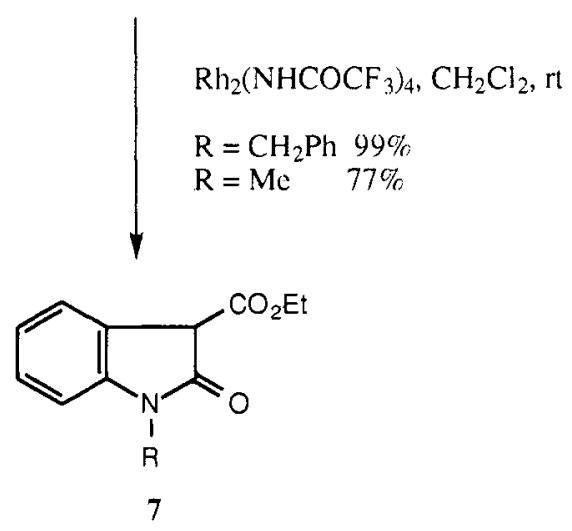<smiles>CCOC1C(=O)N(c2ccccc2)[C@H]1c1ccccc1</smiles>

6

Scheme $3\left\lceil a, \mathrm{R}=\mathrm{Me} ; \mathbf{b}, \mathrm{R}=\mathrm{CH}_{2} \mathrm{Ph}\right\rceil$

\section{Synthesis of Benzofuranones}

Finally the use of intramolecular rhodium carbenoid aromatic C-H insertion reactions was investigated as a route to a model benzofuran unit of diazonamide $\mathrm{A}$. Thus 2 -bromophenol was readily converted into the diazoester $\mathbf{8}$ as shown in Scheme 4. Rhodium(II) catalysed decomposition of $\mathbf{8}$ was complex, and the desired benzofuranone 9 was obtained in only $20 \%$ yield. Subsequent $C$-acylation of 9 in preparation for carrying out another oxazole ring forming step proved straightforward. Thus reaction with ethyl chloroformate in the presence of DMAP ( $c f$. ref 13 ), gave the benzofuranone 10 in $68 \%$ yield. Further elaboration of $\mathbf{1 0}$ is in progress. 
<smiles>Oc1ccccc1Br</smiles>

\section{1. $\mathrm{PhCOCO}_{2} \mathrm{H}, \mathrm{DCC}(75 \%)$}

2. $\mathrm{TsNHNH}_{2}$, then $\mathrm{El}_{3} \mathrm{~N}(63 \%)$<smiles>N=C(C(=O)Oc1ccccc1Br)c1ccccc1</smiles>
$\mid \begin{aligned} & \mathrm{Rh}_{2}\left(\mathrm{NHCOC}_{3} \mathrm{~F}_{7}\right)_{4} \\ & \mathrm{CH}_{2} \mathrm{Cl}_{2} \text {, heat } \\ & (20 \%)\end{aligned}$<smiles>CCOC(=O)C1(c2ccccc2)C(=O)Oc2c(Br)cccc21</smiles>

10

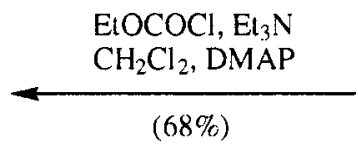

$(68 \%)$<smiles>O=C1Oc2c(Br)cccc2C1c1ccccc1</smiles>

9

\section{Scheme 4}

\section{ACKNOWLEDGEMENTS}

We thank Fisons Pharmaceuticals for their generous support of our research programmes, and Loughborough University and Shell Research for additional support. The work on diazoamides reported here forms part of a much wider study carried out in collaboration with Professor A. Padwa, Emory University, Atlanta, and part funded by NATO (Grant CRG9(0)005).

\section{REFERENCES}

1. N. Lindquist, W. Fenical, G. D. Van Duyne and J. Clardy, J. Am. Chem. Soc., 1991, 113, 2303.

2. For example, see: R. D. Connell, M. Tebbe, A. R. Gangloff, P. Helquist and B. Åkermark, Tetrahedron, 1993, 49, 5445 and references therein.

3. K. J. Doyle and C. J. Moody, Tetrahedron Lett., 1992, 33, 7769.

4. R. L. Danheiser, R. F. Miller, R. G. Brisbois and S. Z. Park, J. Org. Chem., 1990, 55, 1959.

5. For a recent alternative approach to pimprinine, see: P. Molina, P. M. Fresneda and P. Almendros, Synthesis, 1993, 54.

6. G. G. Cox, J. J. Kulagowski, C. J. Moody and E.-R. H. B. Sie, Synlett 1992, 975.

7. For a recent review, see: G. M. Karp, Org. Prep. Proced. Int., 1993, 25, 481.

8. (a) M. P. Doyle, M. S. Shanklin, H. Q. Pho and S. N. Mahapatro, J. Org. Chem. 1988 53, 1017;

(b) M. P. Doyle, M. S. Shanklin, S.-M. Oon, H. Q. Pho, F. R. van der Heide and W. R. Veal, J. Org. Chem. 1988, 53, 3384.

9. N. Etkin, S. D. Babu, C. J. Fooks and T. Durst, /. Org. Chem. 1990, 55, 1093.

10. (a) A. G. H. Wee, B. Liu and L. Zhang, I. Org. Chem. 1992, 57, 44()4; (b) B. Liu and A. G. H. Wee, Heterocycles 1993, 36, 445.

11. (a) L. Staudinger, J. Becker and H. Hirzel, Chem. Ber. 1916, 49, 1978; (b) R. J. Vaughan and F. Westheimer, Anal. Biochem. 1969,29, 305 .

12. We thank Professor A. Padwa, Emory University, Atlanta, for the details of this preparation.

13. T. H. Black, S. M. Arrivo, J. S. Schumm and J. M. Knobeloch, J. Org. Chem., 1987, 52, 5425. 